\title{
PRIESTS' EXPERIENCE OF THE MEANING OF INTEGRITY WITH SPECIAL REFERENCE TO VOCATION
}

\author{
S D. Edwards \& D J. Edwards
}

University of Zululand

\begin{abstract}
In its traditional association with some divine calling, the vocation of priesthood poses great human and spiritual challenges and opportunities along the developmental paths towards personal and ultimate integrity. This study used an interpretive phenomenological paradigm and qualitative research methodology in thematically analyzing and synthesizing the responses of a convenient sample of five Christian priests, four males and one female, with a mean age of 50 years (SD 9.31), with regard to their experiences of the meaning of integrity. Consistent evidence was provided of the depth and meaning attributed to their experience of integrity in personal, interpersonal, congregational and spiritual terms. In addition to appropriate criticism of the Christian religious system and inevitable human failings, the participants provide relevant, authentic evidence of their immersion in their personal, vocational and spiritual choices. Findings, limitations and implications are discussed within the context of psychology of religion.
\end{abstract}

Keywords: Integrity, experience, meaning, priests, vocation, Christianity

\section{INTRODUCTION}

In addition to the common sense connotations of honesty, sincerity and fairness, the concept of integrity has deeper meanings and values, such as wholeness, morality, soundness, intactness and completeness. These deeper meanings include what various knowledge, wisdom and healing traditions throughout planet earth have long recognized as a 
profound oneness or non-duality, framing contemporary converging evidence from various scientific fields of a profound interconnectedness of everything (Lovejoy 1936; Bohm 1993; Gidley 2007; László 2007). Scientific theories, such as integral psychology and psychotherapy typically include some form of integral, dynamic, systemic holism underlying phylogenetic and ontogenetic development (Wilber 1995; Forman 2010). From the perspective of psychological development, substantial evidence exists as to the construct value of Eriksen's (1993) psychosocial developmental theory, which consists of eight or nine, relatively pre-potent life stages and associated crises, from which emerge typical adaptive strengths (Dezutter et al. 2013; Marcia \& Josselson, 2013). The eighth stage is characterized by psychosocial crises involving experiences of integrity or despair, successful resolution of which leads to wisdom (Johansson 2002; Hearn et al. 2012). Stages are not necessarily related to chronological age in Eriksen's theory, which also carries the implication that, although optimal integrity may only be realized in the eighth stage, or even final, ninth stage, earlier forms of integrity, such as the abovementioned common sense variety, can be apparent throughout earlier stages (Erikson \& Erikson 1998).

This psychology of religion study was motivated by the recognition that the priesthood is unlike other vocations in the sense that it has also been traditionally associated with some divine and/or holy calling. In the Christian context of the present study, this is referred to as "a holy calling, not according to our works, but according to His own purpose and grace" (II Timothy 1:6,9). In addition to progressing through the typical developmental tasks and stages of all other human beings towards Erikson's eighth integrity stage, persons experiencing holy callings must also inevitably face 
considerably greater human, social and spiritual challenges required by their holy vocations as evident in, perhaps surpassing, such diverse tasks as traditional ministry, parish administration, stewardship, pastoral care and counselling. There was the consideration that, although their vocation would inevitably expose them to the trials, tribulations and temptations of other mortal, vulnerable human beings, such activities as contemplation and action, based on Jesus Christ's divinely inspirational commandments of loving God and neighbours, could conceivably also provide opportunities and possibilities for greater qualities of integrity than other persons, of such qualities described in psychological literature as aligning the personal and universal will in Selfrealization, Unity Consciousness and/or the Supreme Synthesis (Maslow 1970; Wilber 2007; Assagioli 2012).

It was therefore decided to conduct an exploratory qualitative phenomenological investigation into a small convenience sample of priests' experience of the meaning of integrity. To the best of the authors' knowledge, as supported by extensive literature search, no previous study has specifically addressed the open-ended research question as to the content, mode and manner in which priests would describe these experiences. The personal and sensitive nature of the investigation mandated appropriate ethical considerations and procedures.

\section{METHOD}

\section{Research Design}

An interpretive paradigm, which involved qualitative research methods and techniques, was used. 


\section{Sample}

The sample consisted of five Anglican Church priests, four males and one female, with an age range of 37 to 60 years, mean age of 50.20 years and standard deviation (SD) of 9.31. Participants were selected on qualitative research grounds of experience, insight into, commitment and willingness to discuss their perceptions of the meaning of integrity with special reference to vocation.

\section{Ethical Procedures}

Necessary university ethical clearance was obtained. Informed consent, with guaranteed confidentiality, was obtained from the participants.

\section{Data Collection and Analysis}

Participants were asked to complete the following qualitative question: "Please describe your experience of the meaning of integrity". While the general research approach was interpretive, hermeneutic and phenomenological in orientation, participants' experiential narratives were also informative and instructive. Thematic content analysis and synthesis was therefore preferred to more specific phenomenological techniques of data analysis and synthesis. Participants' experiential narratives were thematically analyzed individually and collectively synthesized.

\section{RESULTS}

The five individual verbatim profiles, codenames $A$ to $E$ are followed by their thematic analysis in italics, all of which are followed by the collective synthesis of experiential meanings. 


\section{Individual Profiles}

A: "I take integrity to mean doing what I say I am going to do when I say I am going to do it. This stands well in relation to others and, of course, to God. I am frustrated when this same kind of thing is not offered by colleagues and perhaps less understanding towards them than I am towards others (congregation members etc.). Often integrity appears to be missing from the system that vocation is caught up in." Integrity means moral consistency in personal, religious, and community relationships. Its lack in colleagues and the religious system is frustrating.

$B$ : "There are two primary but related senses in which 'integrity' is commonly understood - but both are entirely appropriate to vocational ministry; (a) The trustworthiness of a person, entailing their levels of honesty and reliability (b) The connectedness and consistency of a person. In the Church, both are deemed essential to a person's qualification to minister. Yet the truth is that no one has ever entirely succeeded in avoiding hypocrisy or unreliability. There is always a gap between what is professed or claimed, and the life led. If it were not for the uniquely Christian doctrines of grace and redemption being central to the belief system, nobody would ever be allowed to occupy such roles. So in practice the issue is a matter of the extent of a person's integrity, and their self-awareness or honesty. Paradoxically, those who seem to show the greatest integrity are those who can be relatively open about their lack of it. I am more inclined to trust an individual like this, than someone who gives the impression of omni-competence and reliability." Integrity means trustworthiness, honesty, reliability, connectedness and consistency. Their ultimately unattainability requires grace, redemption, insight into, and relative openness about, personal limitations. There is more inclination to 
trust individuals who are open about their relative lack of integrity than those giving inauthentic impressions of competence and reliability.

C: "I believe a priest is called to have both theological and personal integrity, which I feel intertwine and feed into each other. This integrity is to be lived out within the community he or she serves and the worldwide Church but most importantly because as Christians God has called each one of us to be true to Him, ourselves and others. The experiences of my calling, discernment, training, and my vocation to be a priest, have brought the meaning of integrity to the forefront. To take on any role of leading, teaching, guiding, and serving other people I believe one must keep one's integrity in check. For me the deepest sense of integrity is honesty with oneself. I believe for me this is achieved through maintaining a close loving relationship with God my Father and Creator. If I am not true to whom I really am and who I have been created to be or become, I will be a fool to myself and to others around me. If I profess what I do not believe, I am not being true to God, myself and others around me. Discovering one's theological integrity and one's personal integrity is a lifelong journey. There are of course guidelines set out by the church, by the culture we are surrounded by and what is perceived to be common decency, however like so many others I struggle with some of these notions when justice and compassion are compromised and need to question and challenge them. If I use the basis of my upbringing, my education, those whom I have been surrounded by, I probably have a good sense of honesty, common decency, justice, and compassion. This is, of course, sometimes fallible and must evolve. If I were to set myself guidelines to work from Christ's teaching is not difficult to follow, simply; Love God, love others as I love myself." Theological and personal 
integrity are intertwined, mutually reinforcing, and require being lived out in the priestly vocation, which is a lifelong journey. The deepest integrity is honesty with oneself, which is achieved through loving relationship with God. Honesty, authenticity, truthfulness and decency are required in personal and spiritual relationships to both challenge notions when justice and compassion are compromised as well as follow Christ's loving commandments.

D: "Integrity in doctrine. The most important aspect of integrity is to preach the gospel from scripture and not edit it to make it more palatable to peoples' ears. Integrity in preaching. There is a particular temptation in preaching to slightly bend the truth when telling stories or using illustrations, or even in your interpretation of scripture to make the sermon funnier, clearer, more hard hitting. Integrity in speaking. This is an important subset of the need to have a consistently Godly character. It is really important not to speak about others behind their backs. Having been on the other side of it, ie where I have heard a leader speak about others behind their backs I realise how damaging it is. The result is that you don't trust that leader; you don't know if they are on your side, because you don't know what they are saying about you behind your back. Integrity in belief. There is a temptation in ministry to speak confidently about the doctrines of the faith, exhorting others to believe them whilst having doubts yourself. Integrity in character. It is so important to practice what you preach. Having been on the other side of it where I have seen leaders who appear one way in public but are different in private I realise how important this is. It is corrosive to the congregations' faith when they realise that the minister is not an example to follow. The overall challenge of leadership. The previous two examples are part of something that I think I probably find the hardest thing when 
it comes to integrity: knowing how much to reveal of your own weakness and sin to those you are pastoring. _When you are a minister you are aware of your position of leadership. You are aware of the fact that people look up to you and that you are meant to provide an example to them. You are aware, as in any form of leadership, that you need to inspire and lead people. All of these things meant that it is hard to let people in and see what you're really like. And indeed from a leadership point of view there is something wise about this. However it can also be isolating. And worse than that you feel the temptation to pretend to be better than you are. To not do so is to lack a certain amount of integrity. _On the other side, you know that you are no better than others, you know that to be a Christian is to accept you are weak. Moreover as a Christian leader you perhaps expect to be even more aware than others of your own weakness. So in that sense you want to be vulnerable and let people see your struggles. Getting the balance right is very hard. Integrity in friendships. It can be hard to have good friends from amongst your congregation. This is because very often your biggest struggles and difficulties will come from within the congregation. Therefore it is very difficult to know how honest to be with friends. On the one hand to have integrity would be to tell about your struggles, but this would very often not be appropriated since it would be about another brother or sister. So the other side means that to have integrity means not telling friends in the congregation what is really going on with you - this means you feel isolated. The example of integrity. As in all things Jesus is the best example of integrity. He lived a perfect life. His actions always matched his doctrine. He managed to be a suffering servant at the same time as being the most courageous and inspiring leader the world has ever known. He managed to maintain deep friendships even with those whom he knew would 
let him down in the hours before his crucifixion. He had the courage to preach the gospel without flinching but with love no matter to whom he was speaking and no matter what the cost. And of course most wonderful of all he died to wash away the guilt for all our sin and failure: not least the lack of integrity every minister struggles with." Integrity has various meanings. Integrity in doctrine means unedited scriptural faithfulness. Integrity in preaching means not being tempted to bend the truth. Integrity in belief implies moral consistency._Integrity in character means practicing one's preaching. Integrity in leadership and friendships means knowing how much to reveal of one's own weakness and related ethical implications. As a Christian leader you perhaps expect to be even more aware than others of your own weakness. It is very difficult to know how honest to be with friends. In all matters of integrity Jesus provides the best example; of integrity in action, leadership, friendship, preaching, courage, humility and ultimate love.

$\mathrm{E}$ : "My experience of the meaning of integrity is related to the extent to which what is set out accords to reality. So, parental upbringing (my own), although costly, since my father died of an illness when I was a young boy, was consistent and authentic according to my parents' model of what was required of them as workers called by God. This example imprinted itself on me as I grew in my own understanding and as a young man I was conscientious, over-anxious, as I now see myself in retrospect due to the patterns laid down at that time. 'Give of your best' was what I was told. I am now more confident of my integrity but recent personal crisis brought an unexpected attack on it which changes in thinking, prayer and support of others have warded off." Personal integrity, in reality, becomes consistent and authentic, in re- 
lation to upbringing, understanding of God's calling, conscientiousness, reflexivity and confidence.

\section{Collective profile}

The collective profile reveals that the sample of five priests' experience integrity to include: common sense as well as deeper and interconnected meanings of integrity with special reference to themselves, their colleagues, congregation, religious system, Jesus Christ and the Godhead. Specific meanings and contexts attached to the experience include moral consistency in personal, religious, and community relationships as well as frustration with its lack in colleagues and the religious system The ultimately unattainability of integrity requires grace, redemption, insight into, and relative openness about, personal limitations. Personal integrity is achieved through loving relationship with God in order to both challenge notions when justice and compassion are compromised as well as follow Christ's loving commandments. In addition integrity includes personal insight, reflexivity, confidence, scriptural faithfulness, truthful preaching, practicing one's preaching, knowing how much to reveal of personal weaknesses and awareness of related ethical implications. In all matters of integrity Jesus provides the best example of integrity in action, leadership, friendship, preaching, courage, humility and ultimate love.

\section{DISCUSSION}

The following discussion explicates and interprets the findings of the thematic analysis and synthesis in greater depth. Since the seminal works of pioneers such as William James, Theodore Flournoy and Carl Jung the Psychology of Religion has developed steadily as an academic discipline and practice. Consequent to his own spiritual crises, Carl Jung received just recognition for penetrating, depth psychological 
analysis of typical trials and tribulations faced by spiritual persons on their way towards redemption, individuation and/or ultimate Self-realisation (Brooke 1991, 2000; Owens 2011). Jung's analysis included both personal and clients' psychotherapeutic experiences. In Aion (Jung 1959) Jung addresses Christianity's central figure, Christ, and unpacks the meaning of Christ as a symbol of the Self, in its totality, including shadow and syzygy, and differentiated context of Jesus, the historical figure from Nazareth, and the archetypal or risen Christ. Owens (2011:277) notes Jung's account of the dream that led him into the writing of Aion: "Christ-not the man but the divine being-was my secret goal. It came to me as a shock, as I felt utterly unequal to such a task."

Jung (1959:68-70) describes his psychological route to his goal as follows: "Modern psychology is therefore confronted with a question... Is the self a symbol of Christ, or is Christ a symbol of the self? In the present study I have affirmed the latter alternative", and subsequently notes; "This archetypal route does not in any way circumvent the Christian mystery; rather, it forcibly creates the psychological preconditions without which "redemption" would appear meaningless." Redemption" does not mean that a burden is taken from one's shoulders which one was never meant to bear. Only the "complete" person knows how unbearable man is to himself. So far as I can see, no relevant objection could be raised from the Christian point of view against anyone accepting the task of individuation imposed on us by nature, and the recognition of our wholeness or completeness, as a binding personal commitment. If he does this consciously and intentionally, he avoids all the unhappy consequences of repressed individuation. In other words, if he voluntarily takes the burden of completeness on himself, he need not find it "happening" to him against his will in a negative form. 
This is as much as to say that anyone who is destined to descend into a deep pit had better set about it with all the necessary precautions rather than risk falling into the hole backwards."

From the perspective of the perennial philosophy, Jung's (1959) choice may be viewed as one of soul before spirit, where soul refers to the embodied, individual expression of spirit and spirit to the universal expression of soul (Huxley 1946; Judith 2004). This is also a relatively psychological route as distinct from the more monastic and/or conventional Christian route of a life "in Christ". The distinction is developmentally hierarchical in Wilber's (2000) integral theory. Viewing the self as symbol of Christ, may imply even more to the vocation of priesthood, which requires total immersion in this chosen path, a life pattern of striving for unity consciousness or union with the teaching of Jesus and divine life of the reborn, risen Christ. This may mean an orthodox life of contemplation through unfolding developmental stages of consciousness such as metanoia (conversion), apathea (purification), illumination and theosis, or union with God (Chirban 2007). For Thomas Merton (2006:547-550), such contemplation and action is the highest expression of intellectual and spiritual life. It involves an awareness and response to a call that comes from "Him who has no voice". This sublime invitation involves the death of an older life in order to enter a higher life and reborn Self. It is compatible with all things, because it is their highest fulfilment as in the realizations: "I AM" and "I no longer live but Christ lives in me". However, ultimately one cannot teach contemplation as this grace, like everything else, is God given. "The best you can do is write something or say something that will serve as an occasion for someone else to realise what God wants of him". 
Whether priests follow first or second routes, the same personal, developmental end point of integrity, including personal, spiritual, transpersonal selves and ultimate Self (Assagioli 2012), others and God are implied. Metaphorically this requires the practical Christian vocation of fisherman or fisherwoman, enabled to breathe the ethereal Holy Spirit while regularly reaching into the deeper regions of the sea to help other suffering fish, all instructed through the radiant Christ's Godly connectivity. As epitomized in the life of Jesus and evident in the priests' descriptions, this vocation inevitably involves a life of suffering and hardship, unending earthly trials, tribulations and temptations as well as the supreme and ultimate integrity of a Kingdom of Heaven. Whatever the freedom of exegesis, and however much they guard against this, as explicitly expressed by participant D, by virtue of their humanity, priests will also, probably and inevitably, to greater or lesser extent, distort biblical interpretations, in terms of their unique, personal, conscious and unconscious, biases and assumptions. This necessarily implies a lifetime of scriptural scrutiny, intuitions, revelations, personal reflexivity and insight.

Clearly, this is a very limited, exploratory study, with findings that can and should not be generalized or transferred. However, the present sample of priests express various insights, intuitions and revelations in relation to their vocation, with particular emphasis on the conventional Christian route of a life "in Christ". Common sense, deeper and interconnected meanings of integrity are expressed with special reference to themselves, their colleagues, congregation, religious system, Jesus Christ and the Godhead. There is recognition of personal integrity achieved through relationship with God as well as its paradoxical ultimately unattainability. Thus integrity requires vast personal insight and action in all relation- 
ships, personal, social, congregational, spiritual and religious with Jesus Christ providing the ultimate example. The transparent authenticity in B's description, A, C and E's insights and D's detailed examples all relate to what Oxtoby (2012) has referred to as the essence of Christianity, the ethical teachings of Jesus. The foundation of these teachings is self-less, appreciative, non-judgemental, forgiving and compassionate love, as fully explicated in in St Marks' version of Christ's two great commandments (Verse 12:3031) to ' Love the Lord your God with all your heart and with all your soul and with all your mind and with all your strength, and to 'Love your neighbour as yourself'. This ultimately implies constant consciousness and unending praxis in an eternally present, Heaven of Love. St John (Verse 4:8) says: 'Whoever does not love does not know God, because God is love.' In his first letter to the Corinthians (Verse 13:13), St Paul speaks of faith, hope and love, with the greatest being love. By virtue of their calling, the present sample also reflect that very human reality that the first, great commandment of loving God is easier than the second, with all its ultimate implications of loving one's neighbour with one's deepest, broadest, highest, selfless Self as in Christ's example.

However faithfully Paul's teachings may spread the gospel and reflect the loving "mind of Christ" (Devenish 2001), they also appear to have provided some foundation for what, in a psychologically critical, but friendly manner, Oxtoby (2012) has referred to as authoritarian corruption of Christianity, for example, as reflected in fixed, punitive attitudes towards sin and sex, stereotypical typecasting of women as inferior, and generally binary, "either-or" thought patterns that preclude more open minded, "both-and" type processes. Such rigid attitudes and cognitions, along with fundamentalist, discrimi- 
natory, thinking, arbitrary (mis)interpretations of New and Old Testament passages to suit individual and group needs, as well as endemic human greed and power motives, paved the way for many subsequent violent, political, economic, physical, psychological and other abuses, as apparent, for example, in the Crusades, the Inquisition, witch hunts and nefariously unjust systems such as apartheid, all diametrically contrary to the original, moral and ethically orientated teachings of Jesus Christ as reflected in most interpretations of the gospels.

Clearly, any discussion on vocation also relates to the perennially controversial notions of determinism, free will and related philosophical and ethical issues involving vocation, volition, agency and decision making processes. As physical correlate of the present, qualitative phenomenological study, brain imaging techniques such as functional MRI have facilitated objective measurement of introspective data. For example, building on an earlier what, when, and whether (WWW) model of intentional action or decisions, Brass et al (2013) have postulated an anterior-posterior gradient within the medial frontal cortex, whereby broader medial prefrontal cortex (mPFC) based intuitions become funnelled into more specific behaviours associated with the rostral cingulate zone (RCZ), and pre-supplementary motor areas (SMA/preSMA) respectively. These specific behaviours include intentional suspension of volitional control, with regard to which humans seemingly have the ability to veto movements preceded by early brain signals up to 200 microseconds before movement onset (Schultze-Krafta et al. 2016). At least, such research provides some physical basis of hope for discerning intuitions, responsible decisions, and just as well as effective actions by priests of sound moral integrity. 


\section{CONCLUSION}

This study was motivated by the recognition that the vocation of priesthood would pose unique challenges and opportunities for human beings who chose and/or accepted such a vocation. The small sample of five priests who described their experiences of the meaning of integrity provide ample, consistent evidence of the depth and meaning attributed to their experience as well as the great value attached to this construct, personally, collegially, congregationally, in relation to Jesus Christ and the Christian religious system. Consonant with the great valuing of and enormous challenges implicit in their vocation, including its well documented uses and abuses, it seems entirely appropriate that the participants are also critical of the Christian religious system and inevitable human failings including lack of integrity, inauthenticity, hypocrisy, superficiality and incompetence. Despite all this, in their expressed insights, struggles and challenges, the participants provide authentic evidence of their immersion in their personal, vocation, and spiritual choices to continually follow "the narrow way" of a life "in Christ", treading that path of great suffering and great joy towards ultimate integrity with the Godhead, while caring for their congregations.

\section{References}

Assagioli, R. 2012. Psychosynthesis. A collection of basic writings. Amherst, MA: Psychosynthesis Centre.

Bohm, D. 1993. The undivided universe: An ontological interpretation of quantum theory. London, England: Routledge.

Brass, M. et al. 2013. Imaging volition: What the brain can tell us about the will. Experimental Brain Research, 229: 301-312.

Brooke, R. 1991. Jung and phenomenology. New York, NY: Routledge. 
Brooke, R. 2000. Pathways into the Jungian world. New York, NY: Routledge.

Chirban, J., 1985. Development stages in Eastern Orthodox Christianity, in K. Wilber, J. Engler \& D.P. Brown (Eds.), Transformations of consciousness: Conventional and contemplative perspectives on development, 285-314. Boston, MA: Shambhala,

Dezutter, J. et al. 2013. Sense of coherence, depressive feelings and life satisfaction in older persons: a closer look at the role of integrity and despair. Aging \& Mental Health, 7: 839-843.

Devenish, S. 2001. The mind of Christ? A phenomenological explication of personal transformation and cosmic revision in Christian converts in Western Australia. Unpublished $\mathrm{PhD}$ thesis, Edith Cowan University, Western Australia.

Erikson, E.H. 1993. Childhood and society. New York, NY: W. W. Norton \& Company.

Erikson, E.H. \& Erikson, J.M. 1998. The life cycle completed: EXtended version. New York, NY: W. W. Norton \& Company.

Forman, M. 2010. A guide to integral psychotherapy: Complexity, integration, and spirituality in practice. New York, NY: State University of New York Press.

Gidley, J. 2007. The evolution of consciousness as a planetary imperative: An integration of integral views. Integral Review, 5: 4226.

Hearn, S. et al. 2012. Between integrity and despair: toward construct validation of Erikson's eighth stage. Journal of Adult Development, 19:1-20.

Huxley, A. 1946. The perennial philosophy. Glasgow, Scotland: Fontana.

Johansson, C. (2002) Integrity versus despair: An Eriksonian Framework for Geriatric Rehabilitation. Topics in Geriatric Rehabilitation, 17(3): 1-12.

Judith, A. 2004. Eastern Body, Western Mind. Psychology and the Chakra System as a Path to the Self. Berkeley, California: Celestial Arts.

Jung, C. G. 1959. Aion: Researches into the phenomenology of the self. In the Collected Works of Jung, C.G. Vol 9. Part 2: Trans. R. Hull. Edited by Sir Herbert Read, Fordham, M.; Adler, G.; executive editor, McGuire, W.; Bollingen Series XX, 20 volumes. London: Routledge and Kegan Paul, Princeton: Princeton University Press, 1953-1979. 
László, E. 2007. Science and the Akashic field: An integral theory of everything. Rochester, VT: Inner Traditions.

Lovejoy, A.O. 1936. The great chain of being: A study of the history of an idea. Boston, MA: Harvard University Press.

Marcia, J. \& Josselson, R. 2013. Eriksonian personality research and its implications for psychotherapy. Journal of Personality, 81(6): 618-629.

Maslow, A. 1970. The further reaches of human nature. NewYork, NY: The Viking Press.

Merton, T. 2006. 'New seeds of contemplation' (pp. 545-552) in McGinn, B. 2006. The essential writings of Christian mysticism. New York, NY: Random House.

Owens, L. 2011. Jung and Aion. Time, vision and a wayfaring man. Psychological Perspectives, 54: 253-298.

Oxtoby, R. 2012. The authoritarian corruption of Christianity. Cape Town, RSA: New Voices.

Schultze-Krafta, M. et al. 2016. The point of no return in vetoing selfinitiated movements. Proceedings of the National Academy of Sciences, 113(4), 1080-1085.

Wilber, K. 1995. Sex, ecology, spirituality. Boston, MA: Shambhala.

Wilber, K. 2000. Integral psychology. Boston, MA: Shambhala.

Wilber, K. 2007. Integral spirituality. Boston, MA: Integral Books. 